Proc. of the Third Intl. Conf. on Advances in Civil and Structural Engineering - CSE 2015

Copyright (C) Institute of Research Engineers and Doctors, USA .All rights reserved.

ISBN: 978-1-63248-057-6 doi: 10.15224/ 978-1-63248-057-6-51

\title{
Feasibility of Castella Composite Beam as a Structural Element To Receive Earthquake Loads
}

\author{
Mara Junus , Parung Herman, Tanijaya Jonie and Djamaluddin Rudy
}

\begin{abstract}
The purpose of this study was to determine the ability of castella composite beams can be used as a structural element to resist earthquake load based on earthquake resistant building regulations applicable in Indonesia. This research was carried out through testing castella composite beams in the form of a portal with cyclic loading. Solid beams steel used is profiles IWF 2001005.58 fabricated became castella beam. Test beam consists of a solid beam (NB) as a comparison and castella beams with concrete filler between flange or castella composite beam (CCB). The results showed that in terms of the flexure capacity, beam failure at the end of the load, partial ductility and full ductility meet the requirements of SNI 03-1726-2003 on Earthquake Planning Procedures for Building Resilience in Indonesia so castella composite beam $(\mathrm{CCB})$ can be used as a structural element to receive earthquake loads.
\end{abstract}

Keywords : steel, beam ,castella composite, cyclic load

\section{INTRODUCTION}

The need for shelter is increasingly rising day by day in Indonesia in line with population growth. Besides, the land for the construction of buildings or other buildings is more difficult to obtain and the price is higher, especially in urban areas. To save the land, then the solution is to build a multistorey building for office buildings, dwellings or other buildings. Most of the building structure with steel material uses solid steel profiles as advantageous solution in terms of strength and material usage. Experts are trying to structure how to increase the strength of steel elements without an increase in self-weight of steel in order to obtain some new methods that beams with openings entity known as castella beam.

Mara Junus

Hasanuddin University

Indonesia

Parung Herman

Hasanuddin University

Indonesia

Tanijaya Jonie

Hasanuddin University

Indonesia

Djamaluddin Rudy

Hasanuddin University

Indonesia

Research on the angle and length of exposure to a high of 0.60 to a high aperture solid beam has been carried out by
Parung Herman et al (2013) are given monotonic load.. Solid steel profiles fabricated into castella beam is IWF 2001005.5 8. Research on the angle and length beam has been carried out by Parung Herman et al (2013) are given monotonic load. Solid steel profiles fabricated into castella beam is IWF 200 1005.5 8. Research results show the opening angle of $60^{\circ}$ and aperture length $\mathrm{e}=3 \mathrm{~b}=9 \mathrm{~cm}$ gives the best result of the angle and length of openings for openings hexagon. To increase capacity and avoid damage that commonly occur in castella beam, then the beam castella beam reinforced with fresh concrete between the flanges. Their results showed flexural capacity of castella beam with concrete filler between the flange increased $168.34 \%$ compared with the normal beam. The purpose of this study was to determine the ability at the end section of the castella composite beam to receive earthquake loads

\section{Testing Program}

\section{A. Testing Principle}

The principle of the test is based on the structure of the framework that loaded by earthquake load as in Fig. 1(a). By taking part beams and columns that are restricted to the joint (s) Fig. 1(b). Due to horizontal load, the moment at mid beam and column values will be close to zero. Therefore, the position of the zero moment can be modeled as a HINGED, column and beam sections tested are considered to represent part with the end as a HINGE (the moment $=$ ZERO).

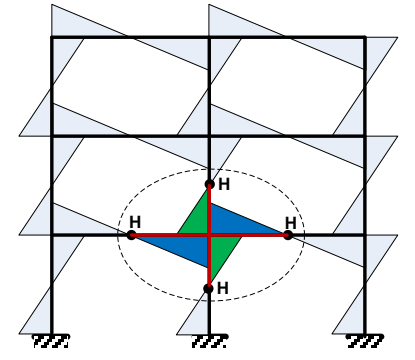

(a)

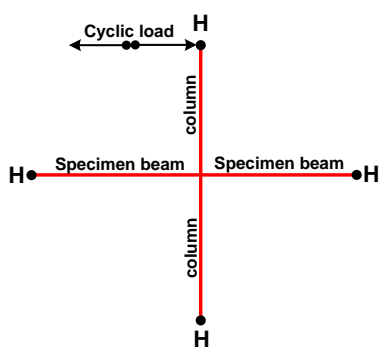

(b)
Figure 1. (a) The moment area of a frame due to earthquake loads, (b) Principle of the test beam element

\section{B. Test Beams}

For specimens, a steel beam used is a profile IWF $200 \mathrm{x}$ $100 \times 8 \times 5.5$ with hexagon shaped openings. High aperture $0.6 \mathrm{H}$, a distance of $9 \mathrm{~cm}$ and the aperture opening angle $60^{\circ}$. The cross section of the test beam as in Fig. 2. Variations of the test specimen consists of a solid beam (NB) as a comparison, and castella composite beam (CCB). The placement of the holes on the castella beam based on a comparison of plastic moments between the solid section and 
Proc. of the Third Intl. Conf. on Advances in Civil and Structural Engineering - CSE 2015

Copyright (C) Institute of Research Engineers and Doctors, USA .All rights reserved.

ISBN: 978-1-63248-057-6 doi: 10.15224/ 978-1-63248-057-6-51

perforated section, assuming when a solid beam section in yielding, then the hole section will also in yielding.

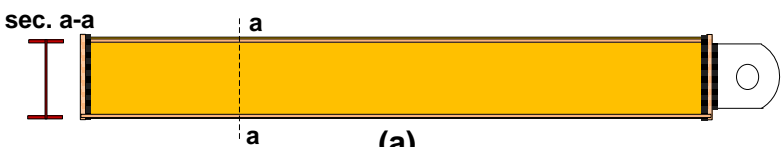

(a)

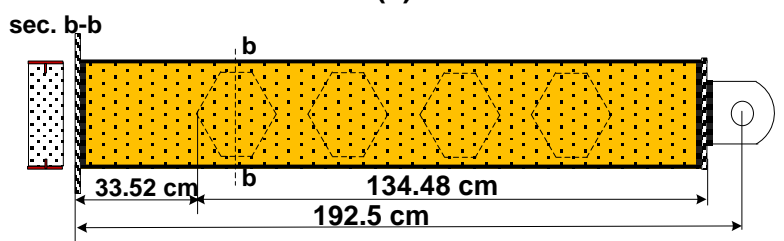

(b)

Figure 2. Beam test for the : (a) normal beam (NB), (b) castella composite beam $(\mathrm{CCB})$

\section{Testing Framework}

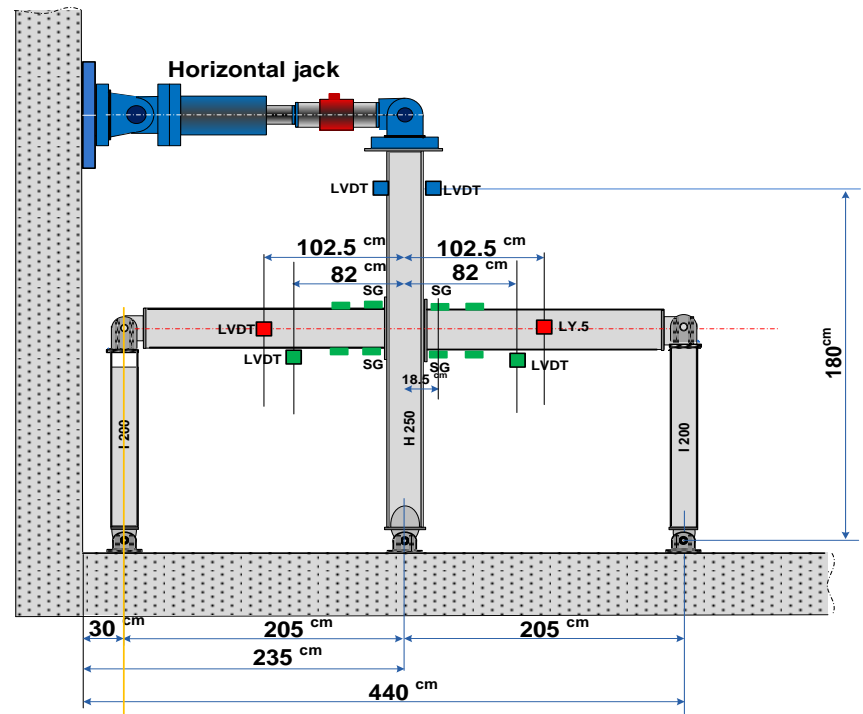

(a)

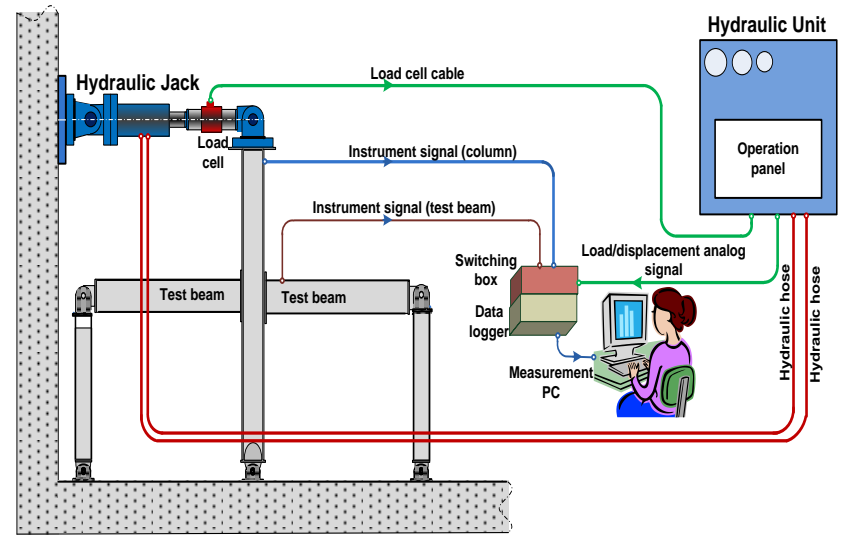

(b)

Figure 3. (a) Framework for testing and placement of testing instruments, (b) testing installation

The testing requires testing framework. Testing framework is designed based on the principle of test as in Fig. 1. Steel beams used are H 250250914 for the middle column and the
IWF 2001005.58 for the other columns Fig. 3. Testing framework laid out on the floor and walls of reinforced concrete. Equipment and testing instruments required are: crane, strain gauge FLK 2.12, LVDT (Linear Variable Displacement Transducer) with a precision of 0.005 and 0.01 , actuator (horizontal jack) with a capacity of $1200 \mathrm{KN}$, logger data and switching box.

\section{Testing Implementation}

The cyclic loading is given in the form of displacementcontrolled at the upper end of the column. Method of loading each cycle based on the Recommended Testing Procedure for Assessing the Behavior of Structural Elements under Cyclic Loads issued by the European Convention for Constructional steelwork (ECCS). The testing stopped when loading cycles plans reached $\mathrm{P}_{\text {failure }}=0.80 \mathrm{P}_{\max }$. (recommendation by ASTM international, designation : E 2126-02a year 2002). Displacement load- ram speed relationship that has been done as shown in Figure 4

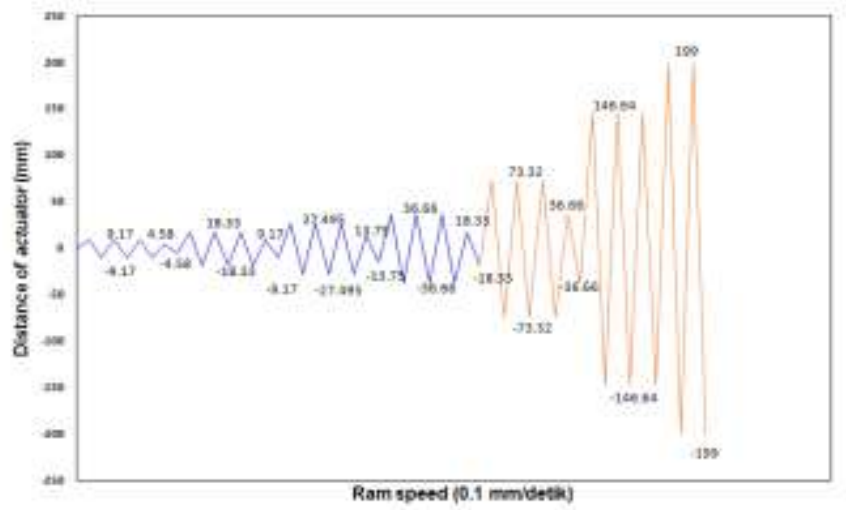

(a)

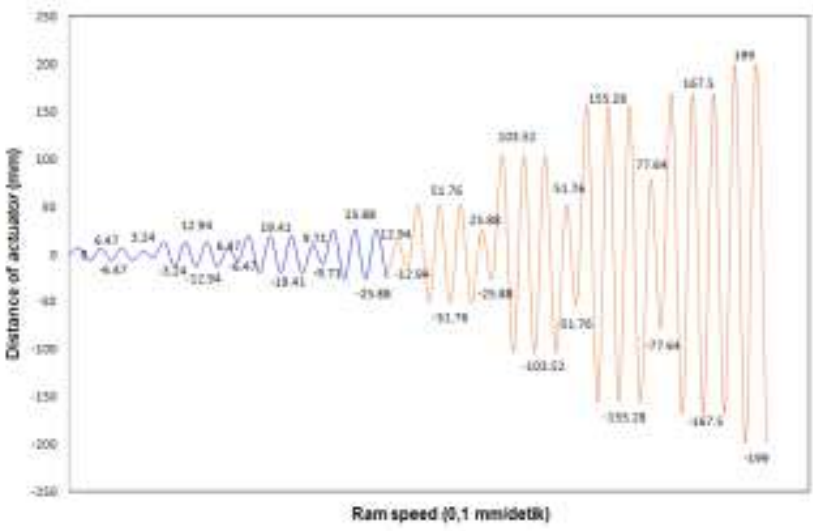

(b)

Figure 4. Displacement- ram speed relationship for the, (a) NB test beam, (b) CCB test beam

\section{Test Results And Discussion}

\section{A. The Maximum Load of the Test Result}

Table 1 shows the load design $\left(\mathrm{P}_{\text {design }}\right)$ and the maximum load $\left(\mathrm{P}_{\text {actual }}\right)$ achieved the 
Proc. of the Third Intl. Conf. on Advances in Civil and Structural Engineering - CSE 2015

Copyright (C Institute of Research Engineers and Doctors, USA .All rights reserved.

ISBN: 978-1-63248-057-6 doi: 10.15224/ 978-1-63248-057-6-51

beam test in testing at the top of the middle column. The maximum load achieved smallest NB test beam is 29.45 $\mathrm{KN}$, and $\mathrm{CCB}$ beam is $84.5 \mathrm{KN}$. From Table 8 above shows; for beams NB, design load is $31.04 \mathrm{KN}$ greater than the actual load of $29.45 \mathrm{KN}$, with a deviation of $5.13 \%$. Design load of CCB test beam is $87.70 \mathrm{KN}$ greater than the actual load of $84.5 \mathrm{KN}$ with a deviation of $3.65 \%$.

Table 1. Design load and the actual load of test beam

\begin{tabular}{cccccc}
\hline Beam test & $\begin{array}{c}\mathrm{P}_{\text {design }} \text { at the top } \\
\text { of column (KN) }\end{array}$ & $\begin{array}{c}\mathrm{P}_{\text {actual min. }} \\
(\mathrm{KN})\end{array}$ & $\begin{array}{c}\text { Deviation } \\
(\%)\end{array}$ & $\begin{array}{c}\text { Final Load } \\
(\mathrm{KN})\end{array}$ & $\begin{array}{c}\mathrm{P}_{\text {failure }}= \\
0.80 \mathrm{P}_{\max }\end{array}$ \\
\hline NB & 31.04 & 29.45 & 5.13 & 21.30 & 24.86 \\
$\mathrm{CCB}$ & 87.70 & 84.50 & 3.65 & 65.50 & 70.64 \\
\hline
\end{tabular}

From the description above shows the beam is weakening faster due to the imposition of back and forth so that the actual load is smaller than the design load. The maximum actual load data in the table shows, the all test beam is already in full plastic condition.

The final load of NB test beam is $21.3 \mathrm{KN}$ already past the deadline for testing requirements are $\mathrm{P}_{\text {failure }}=0.80$ $\mathrm{P}_{\max }$. or equal $24.86 \mathrm{KN}$. The final load of CCB test beam is $65,5 \mathrm{KN}$ already past the deadline for testing requirements are $P_{\text {failure }}=0.80 P_{\max }$. or equal 70,64 KN.

\section{B. Load-Displacement (P- $\Delta)$}

Fig. 5, curve (P- $\Delta)$ with data from the load and displacement of yield condition and final load. NB test beam began yielding in the fourth cycle with load and displacement respectively $24,68 \mathrm{KN}$ and $3,82 \mathrm{~mm}$ at the positive region, and $24,86 \mathrm{KN},-3,72 \mathrm{~mm}$ at the negative region. CCB test beam began yielding in the cycle to VI with load and displacement respectively $54,5 \mathrm{KN}, 4,22 \mathrm{~mm}$ at the positive region and $54,75 \mathrm{KN}, 4,36 \mathrm{~mm}$ at the negative region. The maximum displacement of $\mathrm{NB}$ and $\mathrm{CCB}$ at the final load respectively 20,6 $\mathrm{mm}$ and 22,64 $\mathrm{mm}$.

Displacement at the yield conditions and at the final load conditions determine the partial ductility partial and full ductility value that can be achieved both test beam

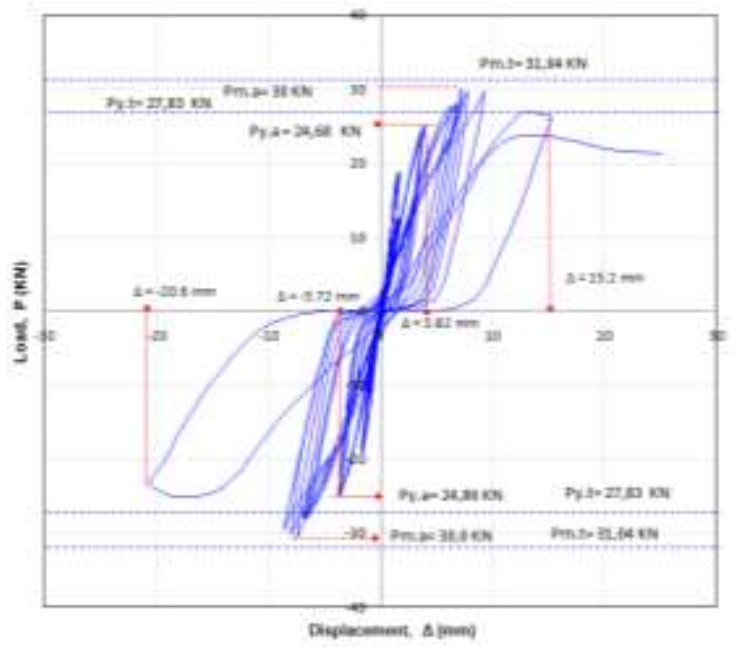

(a)

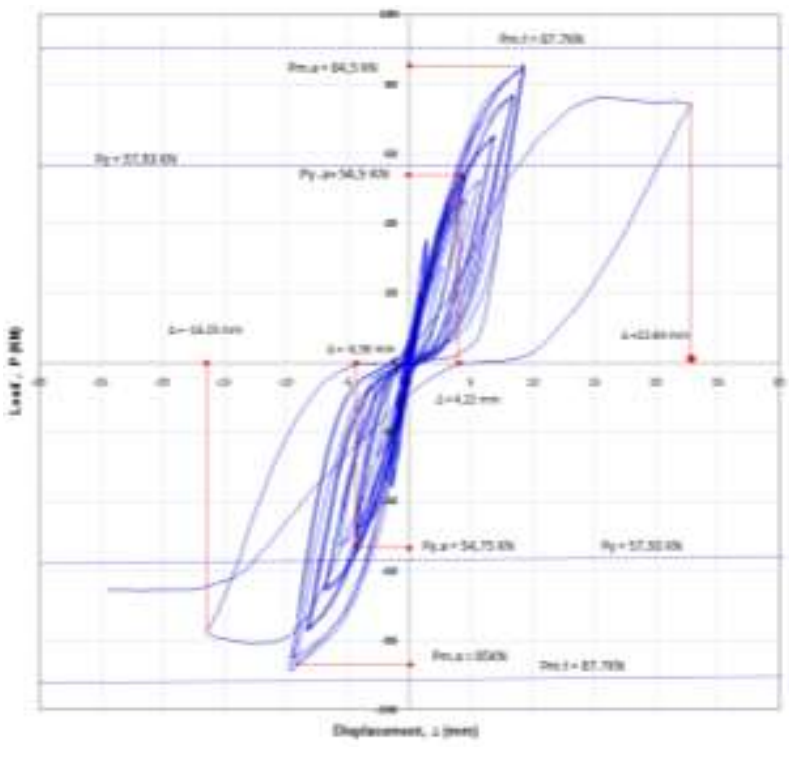

(b)

Figure 5. The load-displacement curve relationship (P- $\Delta$ ) for, (a) NB test beam, (b) CCB test beam

\section{Flexural Capacity}

Table 2. Resistance ratio of the test beam

\begin{tabular}{|c|c|c|c|c|c|c|c|c|c|c|c|c|}
\hline \multirow{3}{*}{ Cyle } & \multicolumn{6}{|c|}{ No } & \multicolumn{6}{|c|}{ CCE } \\
\hline & \multicolumn{2}{|c|}{ P.PO } & \multicolumn{2}{|c|}{$\mathbf{p}, \mathbf{p N}$} & \multicolumn{2}{|c|}{ Anatanes: } & \multicolumn{2}{|c|}{ PMW } & \multicolumn{2}{|c|}{ 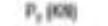 } & \multicolumn{2}{|c|}{ Bnicasese } \\
\hline & $n^{*}$ & n & ni & n. & $\therefore$ & 6 & $n$ & $n$ & ni & $\mathbf{n}$ & $0^{*}$ & 6 \\
\hline 4 & 246 & 20 & 266 & 2456 & 1 & $t$ & & & & & & \\
\hline 4 & 248 & 269 & 264 & $26 \%$ & $1 n$ & 20 & & & & & & \\
\hline (3) & $2 u s$ & 20 & 264 & 245 & in & ta & & & & & & \\
\hline 31 & $m n$ & 279 & 266 & 264 & 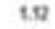 & 18 & MS & 365 & s4s & 3675 & $10 \mathrm{~m}$ & te \\
\hline 12 & $m \mathrm{~m}$ & $m \times$ & $26 \mathrm{kt}$ & $26 \mathrm{~s}$ & 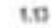 & 18 & Sas & $\operatorname{sen}$ & Jes & 45 & 13 & 18 \\
\hline 53 & $m a$ & 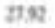 & 248 & $26 \%$ & t. & ta & 42 & 345 & Hes & 405 & 19 & as \\
\hline 4 & sat & 306 & 268 & 248 & in & 13 & 6525 & 683 & 345 & 5675 & 13 & ex \\
\hline $\mathbf{2}$ & 856 & mat & 246 & $24 \%$ & $12 x$ & 134 & 475 & $65: 5$ & ses & 5475 & in & in \\
\hline 13 & Sw & 2465 & 2640 & 2606 & 120 & m & 5023 & 6525 & 545 & 545 & 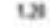 & 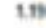 \\
\hline 1.4 & & & & & & & $36 \pi$ & 765 & S4s & 345 & th & $t a$ \\
\hline 12 & & & & & & & $\mathrm{kr}$ & nats & sis & sers & th & $t=$ \\
\hline 13 & & & & & & & ws & Nas & s45 & $\operatorname{sen}$ & in & 13 \\
\hline 4 & & & & & & & $\sin$ & $\boldsymbol{E}$ & jus & $\operatorname{ses}$ & (1)1 & 15 \\
\hline$n$ & & & & & & & Das & m.2 & ses & 5675 & 13.4 & w \\
\hline 13 & & & & & & & 봉 & n & S45 & 405 & in & 논 \\
\hline
\end{tabular}

Tab. 2, The list of resistance ratio $\left(\varepsilon=\mathrm{P}_{\mathrm{i}} / \mathrm{P}_{\mathrm{y}}\right)$ for the test beams at yielding and maximum condition. Based on the minimal of $\mathrm{P}_{\max }$ at maximum load conditions (cycle 6 and 8), the $\mathrm{P}_{\max }$. minimal of $\mathrm{NB}$ and $\mathrm{CCB}$ test beam respectively $29,45 \mathrm{KN}$ and $84,5 \mathrm{KN}$.

Based on these data, flexural capacity of CCB test beam increased by $186.93 \%$ compared to the test beam NB. So, with the addition of the height castella beam without adding steel weight and concrete filler between flange castella beam can improve the flexure capacity of the beam. 


\section{Ductility}

Table 3. Partial ductility of test beam

\begin{tabular}{|c|c|c|c|c|c|c|c|c|c|c|c|c|c|c|}
\hline \multirow[b]{2}{*}{$\begin{array}{l}\text { Crele } \\
\text { namber }\end{array}$} & \multicolumn{7}{|c|}{ NB } & \multicolumn{7}{|c|}{$\cos$} \\
\hline & $\begin{array}{c}s^{+} \\
(\mathrm{mom})\end{array}$ & $\frac{\Delta}{(\operatorname{mon})}$ & $\begin{array}{c}\Delta^{2} y \\
(\mathrm{~mm})\end{array}$ & $\begin{array}{c}\Delta y \\
(\mathrm{~mm})\end{array}$ & $\mathrm{H}_{3}{ }^{*}$ & $\mathrm{H}^{\circ}$ & $\mu_{n} \min$ & $\begin{array}{c}\Delta^{*} \\
\text { (mm) }\end{array}$ & ${ }^{\circ}$ & $\begin{array}{l}S^{5} y \\
\text { (menti }\end{array}$ & $\begin{array}{c}\text { aly } \\
\text { (imonj) }\end{array}$ & $\mathrm{H}_{\mathrm{s}}$ & $\mathrm{B}$ & $\mathrm{H}_{2}=\mathrm{min}$ \\
\hline 4.1 & 3.81 & 3.65 & 3.52 & 3.73 & 0,997 & 0.979 & 1 & & & & & & & \\
\hline 42 & 3.82 & 3.73 & 3.82 & 3.73 & 1 & 100 & & & & & & & & \\
\hline 4.3 & 3.86 & 3. $n$ & 3.82 & 3.73 & 1.01 & 101 & & & & & & & & \\
\hline 5.1 & 6.28 & 6.52 & 1.82 & 3.73 & 1.644 & 1.75 & 1.64 & 4.22 & 4.36 & 4.22 & 4.36 & 1 & 1 & 1 \\
\hline$\$ .2$ & 6n & $6 n$ & 1.82 & 3.73 & 1.752 & 1an & & 4.39 & 4.42 & 4.22 & 4.36 & 1.04 & 1.08 & \\
\hline 3.3 & 6.32 & 6.95 & 3.62 & $3 n$ & 1.512 & 1.36 & & 4,41 & 4.41 & 4.22 & 4.36 & 1.05 & 1.08 & \\
\hline 0.1 & $\pi, 2$ & 7.49 & 3.82 & 2.73 & 1.885 & 201 & 1.89 & 689 & 6.82 & 422 & 4.36 & 1.63 & 1.96 & 1.50 \\
\hline 5.2 & 775 & 8.01 & 1.82 & 3.73 & 2.029 & 2.15 & & 6.56 & 6.80 & 4.22 & 4.30 & 2.63 & 1.57 & \\
\hline 6.3 & 9.25 & 869 & 1.82 & 3.73 & 2.421 & 2.33 & & ft:s3 & 603 & 4.21 & 2.36 & 1.62 & 1.57 & \\
\hline 7,1 & 15.2 & 20.6 & 3.82 & 3.73 & 3.98 & 5.92 & & 1.46 & 8.2 & 4.22 & 4.36 & 2.01 & 1.83 & 1.63 \\
\hline 7.2 & 25.2 & & 3.82 & 9.73 & 6.60 & & 6.6 & B. 4 & $=2.35$ & 4.22 & 4.36 & 1.99 & 1.92 & \\
\hline 2.3 & & & & & & & & H.37 & 82 & 4.22 & 4.36 & 1.99 & 1.6s & \\
\hline .4. & & & & & & & & 9.3 & 9.27 & 422 & 4.96 & 2.21 & 2.13 & 2.13 \\
\hline 8.2 & & & & & & & & 9.28 & 9.65 & 422 & 436 & 2.2 & 2.21 & \\
\hline 8.3 & & & & & & & & 9.77 & 9.47 & 422 & 430 & 2.32 & 2.17 & \\
\hline 91 & & & & & & & & 2264 & 16.20 & 4.22 & 436 & 5.37 & 3.73 & \\
\hline 9.2 & & & & & & & & & 24.4 & 4.22 & 436 & & 3.60 & 5.6 \\
\hline
\end{tabular}

Tab. 3 list of partial ductility from yield condition to final load. At the final load $\left(\mathrm{P}_{\text {failure }}=0.80 \mathrm{P}_{\max }\right)$ partial ductility $\left(\mu_{\mathrm{o}}\right)$ of NB and CCB test beam respectively 6,6 and 5,6. These data indicate partial ductility of CCB test beam smaller $17.86 \%$ compared with test beam NB. This is caused by the increased rigidity of the beam due to the concrete filler between the flange beams castella so that minimize displacement value.

Table 4. Full ductility of test beam

\begin{tabular}{|c|c|c|c|c|c|c|c|c|c|c|c|c|c|c|}
\hline \multirow[b]{2}{*}{$\begin{array}{l}\text { Creie } \\
\text { number }\end{array}$} & \multicolumn{7}{|c|}{ NB } & \multicolumn{7}{|c|}{$\mathrm{COB}$} \\
\hline & $\begin{array}{l}\Delta \theta^{*} \\
(\mathrm{~mm})\end{array}$ & $\stackrel{\mathrm{Am}}{\text { (inom) }}$ & $\begin{array}{l}\Delta{ }^{2} y \\
(m m)\end{array}$ & Siv & $n^{*}$ & $H_{n}{ }^{\prime \prime}$ & $H_{i} \min$ & $\begin{array}{l}\text { Adi, }^{\prime} \\
\text { immi }\end{array}$ & AMt & $\begin{array}{c}\Delta x y \\
\text { (ines) }\end{array}$ & Siv & $\omega_{1}{ }^{*}$ & $\omega^{*}$ & $14, \min$ \\
\hline 4.1 & 3.9 & 4 & $3 . \mathrm{ER}$ & in & 1.07 & 1.07 & 1.02 & & & & & & & \\
\hline 42 & 4.07 & 4.33 & 1.18 & in & 1.07 & 1,16 & & & & & & & & \\
\hline 4.3. & 4.11 & 4.37 & 1.62 & $M n$ & 1.64 & 1.17 & & & & & & & & \\
\hline 5.1 & 6.6 & 702 & 1.n & in & $\ln$ & 1.an & 1.73 & 4.61 & 4.51 & $4 n$ & 4.36 & 1.09 & 1.03 & 1.03 \\
\hline 5.2 & 7,71 & 7.34 & 3.e & $\sin$ & 2.02 & 1.97 & & 4.73 & 4.67 & 4.22 & 4.36 & 1.12 & 1.07 & \\
\hline 5.3 & 7.91 & 257 & 1.12 & in & 2.07 & 2,03 & & 4.8 & 4.54 & 4.22 & 4.36 & 1.14 & 1.04 & \\
\hline 6.1 & 7.65 & 9.19 & 3.52 & 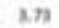 & 2 & 2.46 & 2.00 & 7.27 & 7.28 & 4.2 & 4.36 & 172 & 1.66 & 1.66 \\
\hline 6.2 & 0.55 & $9 . n$ & 3.62 & in & 25 & 2.61 & & $7.2 \mathrm{n}$ & 7.24 & $4 n$ & 4.36 & $1 . n$ & 1.66 & \\
\hline 6.3 & 11.4 & 10.4 & 3.52 & $\sin$ & 2.99 & 2.79 & & 7.33 & 7.25 & $\operatorname{sn}$ & 4.36 & 174 & 1.66 & \\
\hline 7.1 & 17.1 & 22.3 & 3.52 & A.n & A.4A & 5.41 & & 9.1 & 8.98 & 4.22 & A. 36 & 2.166 & 2.06 & 2.02 \\
\hline 7.2 & 27.4 & & 3.12 & an & 7.17 & 0 & 7,17 & siss & 6. 74 & $\sin$ & a.36 & 2.1 & 2.02 & \\
\hline 7.3 & & & & & & & & $\mathbf{2} .70$ & A. A. & 1.22 & A.36 & 2.as & 2.03 & \\
\hline B. 1 & & & & & & & & 9.5 & 9.82 & 4.22 & 4.36 & 2.32 & 2.25 & 2.24 \\
\hline B.2 & & & & & & & & 10.8 & 10.34 & 1.23 & a. 36 & 2.57 & 2.37 & \\
\hline 1.3 & & & & & & & & 11.3 & 10.31 & $14 \pi 2$ & 4.36 & 260 & 2.36 & \\
\hline 9.1 & & & & & & & & 24.5 & 17.23 & 4.22 & 4.36 & 5.6 & 3.55 & \\
\hline 9.2 & & & & & & & & & 26.70 & 4.27 & a.,36 & 0 & 612 & 6.12 \\
\hline
\end{tabular}

Tab.4. list of full ductility from yield condition to final load. At the final load $\left(\mathrm{P}_{\text {failure }}=0.80 \mathrm{P}_{\max }\right)$ full ductility $(\mu)$ of $\mathrm{NB}$ and $\mathrm{CCB}$ test beam respectively 7.17 and 6.12 . These data indicate full ductility of CCB test beam smaller $17.16 \%$ compared with test beam NB. This is caused by the increased rigidity of the beam due to the concrete filler between the flange beams castella so that minimize displacement value.

According to SNI 03-1726-2003 on Earthquake Resilience Planning Procedures for Building Article 3.1.2.3 states structure should achieve full ductility $(\mu)$ of 5.20.

Full ductility test beam at 6:12 CCB greater than the regulatory requirements that apply in Indonesia. Under the provisions above, CCB beams can be used as a structural element for receiving seismic load.

\section{E. The Failure of the Test Specimen}

Based on a local failure of the beam theory which states that; if $\lambda \mathrm{G} \leq \lambda \mathrm{p}$ then the beam will failure due to yielding. From Table 3 shows the beam NB, and CCB with $\lambda \mathrm{G}$ of 6.25 is smaller than $\lambda p$ at 10.97. This shows flange beams NB, and
CCB will fail due to yielding. Evaluation is based on ASTM international , designation: E 2126-02a year 2002, at $\mathrm{P}_{\text {failure }}=$ $0.80 \mathrm{P}_{\max }$

\section{a. The failure of NB test beam.}

Flange buckling occurs early on in the cycle to $\mathrm{V}$ with the flexure moment $\left(\mathrm{M}_{\mathrm{t} . \mathrm{a}}\right)$ of $41.82 \mathrm{KN}-\mathrm{m}$ and strain $\left(\varepsilon_{\mathrm{t} . \mathrm{a}}\right)$ 8936 for micro strain greater than the yielding strain $\left(\varepsilon_{\mathrm{y}}\right)$ of 1200 micro-strain. Buckling process goes on until the end of the loading with maximum strain value $\left(\varepsilon_{\text {m.a }}\right)$ of -15082 micro strain and steel stress $\left(f_{s}\right)$ of $281.05 \mathrm{MPa}$. NB beam flange buckling at the end of the loading is already a permanent buckling. Figure 6 shows the maximum strain values obtained from the test data and stress value calculated theoretically based on the maximum load test results. Shear stress occurs (T) of $25 \mathrm{MPa}$ less than the yield stress (fy) of $240 \mathrm{MPa}$. This shows the beam does not fail due to shear.

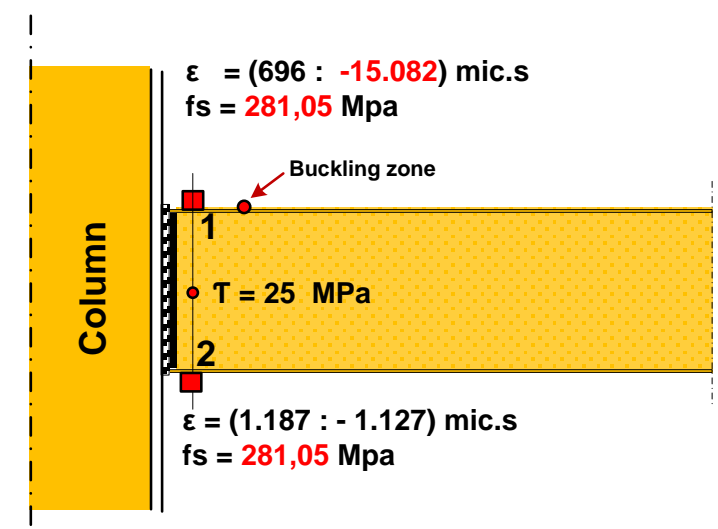

Figure 6. Stress and strain maximum at NB test beam

\section{b. The failure of CCB beam test}

Initial cracks of concrete on the bottom side due to the thrust load cracking moment $\left(\mathrm{M}_{\text {cr.a }}\right)$ of $77.32 \mathrm{KN}-\mathrm{m}$ and strain $\left(\varepsilon_{\text {cr.a }}\right)-5979$ micro stain or strain in the cross-section $\mathrm{T}$ of 8775 micro-strain. Concrete cracks started from bottom side creeping into the middle of the beam section. Concrete cracks on the upper side starts from upper side creeping into the middle of the beam section. The cracks pattern is vertical caused by the flexural moment. The process of cracks along the beam span lasts until the end of the loading with maximum strain value $\left(\varepsilon_{\mathrm{m} . \mathrm{a}}\right)$ of 7821 micro strain on the top flange of the $\mathrm{T}$ beam and maximum strain value $\left(\varepsilon_{\mathrm{m} . \mathrm{a}}\right)$ of 12166 micro strain on the bottom flange of the $\mathrm{T}$ beam with steel stress $\left(\mathrm{f}_{\mathrm{s}}\right) 341.23 \mathrm{MPa}$. Figure 7 shows the maximum strain obtained from the test data and the maximum stress is calculated based on the maximum load test. Shear stress $(T)$ in cross section near the joint is $19.10 \mathrm{MPa}$, vertical shear stress $\left(\mathrm{T}_{\mathrm{v}}\right)$ and horizontal shear stress $\left(T_{h}\right)$ on a solid web between two holes castella respectively $29.5 \mathrm{MPa}$ and 83.6 MPa, and web buckling stresses $\left(\mathrm{f}_{\mathrm{tk}}\right)$ is $129.45 \mathrm{MPa}$. The third stress is still lower than the yield stress steel (fy) $240 \mathrm{MPa}$. This shows the failure of CCB beam was not caused by the three types of stress 


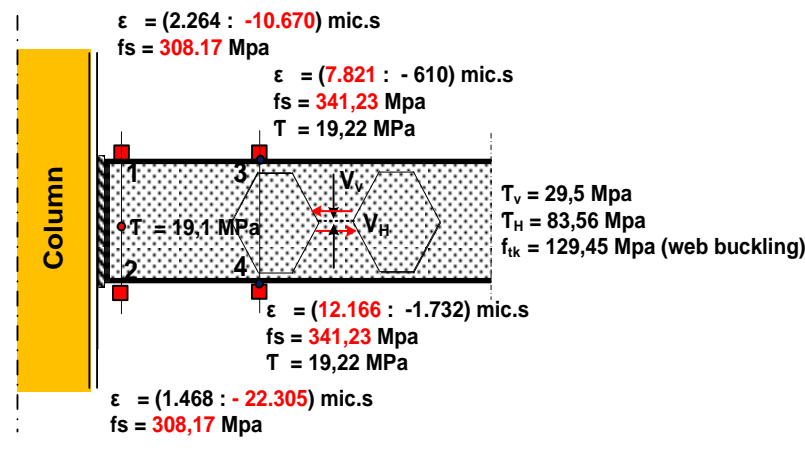

Figure 7. Stress and strain maximum at $\mathrm{CCB}$ test beam

Load at the end of the loading of $65.5 \mathrm{KN}$ already past the deadline for testing requirements that are $\mathrm{P}_{\text {failure }}=0.80$ $\mathrm{P}_{\max }$. or equal $70.64 \mathrm{KN}$.

From the description above indicate that, NB beams failed due to yielding. Stress and strain that occurs already exceeded steel yield stress and strain of steel. Stress and strain of steel will increase continuously along with the addition of each load cycle. Both of these conditions will cause the elastic modulus of the steel progressively decreases so that the flanges are buckled at each change of direction of the load is not able to return to its original position so that the beam flange buckled permanently. This condition also occurs in the CCB beam. With the stress and strain of steel that has exceeded from the yielding stesses causes deformation of the beam increases continuously which causes the top and bottom concrete alternately attracted in the direction of the turn of the load and when the tensile stress that occurs exceeded of the concrete tensile stress, concrete is cracked. Failures in the local buckling on flange of NB beam is not occur on the CCB beam. This shows the function of the concrete filler between the flange prevents flange and web buckling of the beams. Until the last loading, the second beams do not show the failures models like at the beam due to monotonic loading and beam damage is not significant until the loading limit.

\section{iv. Conclusions}

From the discussion above, a number of conclusions as follows :

[1] Fabrication normal beam into a castella beam with concrete filler between the flange (CCB) does not add to the weight of steel and can increase the flexure capacity of $186.93 \%$ when compared with the normal beam (NB)

[2] Partial ductility and full ductility value of the CCB beam eligible in accordance with SNI 03-1726-2003 on Earthquake Planning Procedures for Building Resilience in Indonesia.

[3] Until the end of the limit load, CCB beam damage is not significant and the damage in the form of concrete cracks can be repaired

[4] Based on the conclusions 1,2 and 3 showed CCB beam can be used as a structural element due to receiving seismic load

\section{References}

[1] Anonym. ASTM international designation : E 2126-02a. Standard Test Method for Cyclic (Reversed) Load Test for Shear Resistance of Walls for Building. Copyright @ ASTM International,100 Barr Harbor Drive. PO Box C 700, West Conshohocken, PA 19428-2959, United States, 2002

[2] Anonym. Recommended Testing Procedure for Assessing the Behavior of Structural Steel Elements under Cyclic Loads. European Convention for Constructional Steelwork

[3] Anonym. Earthquake Planning Procedures for Building . SNI 03-17262003. Department of Public Works. Indonesia.2003

[4] Chung, K.F., Liu, T.C.H. and Ko, A. C. H., Investigation on Vierendeel Mechanism in Steel Beams with Circular Web Opening. Department of Civil and Structural Engineering, The Hong Kong Polytechnic University, Hong Kong, Journal of Construction Steel Research, Vol. 57, pp. 467-490, 2000.

[5] Showkati, H. Theoretical and numerical buckling study of CPE castellated beams. Final report of NRCI1437, Iran, 2002.

[6] Sonck D., Vanlaere W., and Van Impe R. Buckling of Cellular Members loaded by an Axial Force. Proc. Int. Symp. Of the International Association for Shell and Spatial Structures (IASS), pp. 1464-1471, 2002.

[7] Sonck D., Vanlaere W., and Van Impe R. Influence of Plasticity on the Lateral-torsional Buckling Behaviour of Cellular Beams. Materials Research Innovations, Vol. 16 S1, pp. 158-161, 2001.

[8] Wakchaure M.R, Sagade A.V and Auti V.A, Parametric Study of Castellated Beam with Varying Depth of Web Opening. International Journal of Scientific and Research Publications, Volume 2, Issue 8, August 2012.

[9] Parung et al, Experimental Study on Castellated Steel Beam Using Monotonic Loading, ITB Bandung, KNPTS, 2013. 